\title{
Species composition of microbiota of cows udder and raw milk quality at mastitis
}

\author{
A.P. Palii' ${ }^{1 *}$, Y.S. Ulko², O.O. Bogomolov ${ }^{1}$, L.V. Kis-Korkishchenko ${ }^{1}$, M.D. Kambur ${ }^{2}$, \\ A.A. Zamaziy ${ }^{3}$, N.M. Brit ${ }^{4}$, I.M. Boiko ${ }^{4}$, I.V.Grebnova' ${ }^{1}$, Y.O. Kovalchuk ${ }^{5}$, A.P. Paliy ${ }^{6}$ \\ ${ }^{1}$ Kharkiv Petro Vasylenko National Technical University of Agriculture, 44 Alchevskih St., Kharkiv, 61002, \\ Ukraine. \\ ${ }^{2}$ Sumy National Agrarian University, 160 Gerasim Kondratiev St., Sumy, 40000, Ukraine. \\ ${ }^{3}$ Poltava State Agrarian Academy, 1/3 Skovorody St., Poltava, 36003, Ukraine. \\ ${ }^{4}$ Pavlo Tychyna Uman State Pedagogical University, 2 Sadova St., Uman, Cherkasy region, 20300, Ukraine. \\ ${ }^{5}$ Uman National University of Horticulture, 1 Internatsionalniy Prov., Uman, Cherkasy region, 20305, \\ Ukraine. \\ ${ }^{6}$ National Scientific Center "Institute of Experimental and Clinical Veterinary Medicine", 83 Pushkinska St., \\ Kharkiv, 61023, Ukraine.
}

*Corresponding author E-mail: paliy.andriy@ukr.net

\section{Received: 14.07.2020. Accepted: 16.08.2020}

\begin{abstract}
To increase the productivity of cows and improve the nutritional and sanitary-technological qualities of milk is one of the most important tasks in the development of dairy farming in all countries of the world. The cause of degradation of these parameters is such a widespread disease of cows as mastitis. The social significance of mastitis is manifested in the fact that the causative agents of mastitis in cows can cause disease in humans. Since streptococci and staphylococci play a leading role in mastitis, they are the most common in milk. Studies have shown that udder disease in cows with mastitis at the beginning of lactation has a certain seasonal nature and its main peaks occur in March-May and September-November. During these months, from $2.5 \%$ to $4.1 \%$ of cows from the total number of livestock of the farm were found to have mastitis. Physiochemical features of milk from the cows with mastitis were an increase in the number of somatic cells to $1,500,000 / \mathrm{cm}^{3}$, increase of milk $\mathrm{pH}$ to 7.3 , caused by the breakdown of milk proteins into ammonia, the increase in milk electrical conductivity to $5.92-7.54 \mathrm{mS} / \mathrm{cm}$, associated with the entry of sodium and chlorine ions from the blood into the milk. In studies of cows with mastitis, 16 species of bacteria were isolated from the secretion of the udder. In monoculture, the microflora, that was found in $30.5 \%$ of cows, consisted of E. coli, St. epidermidis, $C$. freundi, Sh. Dysentery, St. aureus, St. hyicus spp. Chromogenes, Str. Agalactiae, St. lentus, and St. intermediate. In 69.5\% of cows with mastitis, the microflora was found in various associations. The most common associations of bacteria were St. epidermidis + St. aureus + Str. agalactiae + Str. haemolyticus; E. coli + Str. agalactiae; Str. agalactiae + St. epidermidis; St. epidermidis + St. aureus + Str. agalactiae. We developed a method for diagnosing mastitis in cows, which was to diagnose the disease at early stage of inflammation of the mammary glands by studying the composition of the milk the examined lobe of the udder.
\end{abstract}

Keywords: Milk quality; Mastitis; Bacteria; Monocultures; Microflora; Microorganisms

\section{Introduction}

The development of dairy farming in Ukraine is influenced by the economic situation in the market, the quality of products, and the incidence of dairy herds, which is the most significant. (Bezman et al., 2015; Paliy, 2016; Silva et al., 2016).

Inflammation of the mammary glands in cows is a pathology that is often diagnosed, especially during lactation, when the udder is experiencing heavy loads. Mastitis leads to a decrease in milk productivity, and in some cases causes culling of animals (Palii et al., 2020a). According to Ashraf \& Imran (2018), the amount of sick cows in the herd can be at the level of 10 to $55 \%$, and about $75 \%$ of the herd can suffer from this disease. The appearance and spread of mastitis in cows brings huge economic losses to the producer. The decrease in milk productivity during lactation can reach from 10 to $25 \%$ depending on the age, animal productivity and duration of the disease. Moreover, losses can be as high as 500-700 kg per lactation from one dairy cow milk (Soest et al., 2016). Colostrum and milk obtained from cows with inflammation of the udder reduces the immunity of calves, cause growth retardation, as well as the death of young animals (Palii et al., 2020b; Vliegher et al., 2012).

Cow's udder disease is a serious socio-economic problem. It has been established that staphylococci contained in the milk of mastitis cows can secrete exotoxins that cause gastrointestinal injury in humans (Freitas et al., 2017). There are mass food poisonings of people, especially severe forms of the disease occur in children after consuming milk and dairy products containing pathogenic microorganisms and their products. The production of kefir, cheese, yogurt is problematic when even a small amount (3$5 \%$ ) of mastitis milk gets into the whole milk (substances contained in such milk inhibit the development of lactic acid bacteria). And if the whole milk contains $10-15 \%$ of mastitis milk, it becomes unsuitable for processing. The content of somatic cells in milk increases, the level of lactose, proteins, enzymes and free fatty acids changes. All this leads to changes in the properties, taste and quality of milk, as well as derived products (Bobbo et al., 2017; Heikkila et al., 2018; Shkromada et al., 2019). According to (Haenni 
et al., 2018) the incidence of mastitis in cows is often due to the use of methods and measures that reduce natural resistance of the body. In addition to direct factors, favorable conditions in the etiology of mastitis are: microclimate of the room, design of stalls (boxes), age of animals, lactation stage, hereditary predisposition, hormonal effects, general animal diseases, violations of zootechnical feeding standards, unsanitary conditions of cows, milking hygiene, unsuitability of individual animals for machine milking, etc. (Asma et al., 2019; Paliy et al., 2020).

A microbial factor is of particular importance in the occurrence of mastitis. In this case, microorganisms can be a direct cause of mastitis or complicate the developmental processes in the udder that occur as a result of exposure of the mammary gland to adverse environmental factors (Wente et al., 2019). The inflammatory process in the mammary gland leads to damage and destruction of milk-producing cells, resulting in a bad secretion. It was found (Wolfenson et al., 2015) that, after the animal recovers from mastitis, milk productivity in the next lactation is not restored in almost half of the cows.

Many dairy companies use different schemes to control and rehabilitate herds from diseases of mammary glands. Monthly diagnostic examinations of udder secretion with diagnostic reagents allow monitoring of udder condition in dairy cows in herds (Leimbach \& Krömker, 2018). In addition, the use of new diagnostic methods in veterinary practice can increase the effectiveness of veterinary control and prevent the spread of infection. Nowadays, the study of biological fluid is of great interest in the diagnosis of diseases. So its structural analysis was very informative in the early diagnosis of various human diseases. The method consists in studying the solid phase of a drop of biological fluid under a light microscope. In medical practice, this method is already widely used, but it only finds practical application in veterinary medicine (Buzoverja et al., 2012).

Thus, mastitis occurs in cows of different productivity and causes the significant economic damage to milk producers due to its deficiency and low quality, premature culling, morbidity of newborn calves, and significant treatment costs. Therefore, the development of a method for diagnosing mastitis in cows, based on microscopy of a dried milk crop will allow to detect the latent form of mastitis at the early stages.

\section{Materials and Methods}

The aim of the research was to establish the frequency of subclinical mastitis in cows, its effect on physicochemical parameters of milk with determining the species composition of milk microflora in cows with subclinical mastitis with the development of a method for its diagnosis in the early stages of inflammation $f$ mammary glands. We considered the available literature and performed comprehensive clinical, instrumental and laboratory study of lactating cows with mastitis.

Realization of the set purpose was carried out in the conditions of State Experimental Enterprise 'Kutuzivka' (Kharkiv district, Kharkiv region, Ukraine) under of loose housing of high-yielding cows of the Ukrainian black-spotted dairy breed and double milking on the automated installation of herringbone type UDYA-16A $(2 \times 7)$ of domestic production.

The study was performed during evening milking. Before applying the milking machine, the first streams of milk were fed into the plate (Paliy, 2018). As a control, a settling test was used, which was counted $16-18 \mathrm{~h}$ after holding the tubes with the secretion in the refrigerator at $4-8^{\circ} \mathrm{C}$. The criterion for diagnosis of subclinical mastitis is the symptoms of udder damage. The clinical form of mastitis was detected by examination, palpation, trial milking, as well as by the nature of the clinical condition of the animal's body and its mammary glands. To determine the quality of milk the 'Ecomilk' device KAM 98/2A № 271001/04 according to GOST 2345390 and GOST 30518-97 was used. It was used to analyze the quality of milk.

To determine the species composition of the microflora isolated from the udder, 75 samples of secretions taken from the cows with mastitis were examined. Sampling was performed in accordance with DSTU ISO 707:1997. To do this, before taking the sample, the teats and hands were wiped with a cotton swab soaked in $70-50^{\circ} \mathrm{C}$ ethyl or denatured alcohol, and $5-10 \mathrm{ml}$ of alveolar milk was milked in test tubes. When sampling, care was taken to ensure that the teat did not touch the edge of the tube. The tube with milk (secret) was closed with a sterile cotton gauze or rubber stopper, the nickname or inventory number of the animal, the udder lobe and its condition (healthy or sick) were written on the label. Then, culture replication was made from the taken samples. For the cultivation of microorganisms, Petri dishes with cultures were placed in a thermostat at $38^{\circ} \mathrm{C}$.

Cultural properties were determined by the nature of growth on nutrient media and by the appearance of colonies of microorganisms. The shape of the colonies, their color, size, surface character and transparency were taken into account. When cultures were placed on blood agar the absence or presence of a zone of hemolysis was taken into account. The plates (biochemical differentiating staphylococci and enterobacteria) by BIOVET company, Bila Tserkva (Ukraine), were used to determine the type of bacteria. The species of microorganisms was determined in accordance with DSTU 7357: 2013 and DSTU IDF $100 \mathrm{~B}: 2003$.

The results were presented like arithmetic mean $(X)$, standard error $\left(S_{X}\right)$ and the validility of the differences between the compared indicators $(p)$.

\section{Results and Discussion}

A total of 1,225 lactating cows were subjected to clinical examination from 2017 to 2019. Annual studies of animals with mastitis have shown that the number of positive animals has increased, despite the fact that the number of livestock on the farms remained approximately the same.

Analysis of the obtained materials showed that the incidence of udder diseases in lactating cows with subclinical mastitis was $20.74 \%$ of the total breeding stock, and the incidence of clinical mastitis $-6.82 \%$. If in 2017 mastitis was detected in $36.22 \%$ of animals, in 2018 - in $39.37 \%$, in 2019 - in $43.3 \%$, i.e., the incidence of udder disease with mastitis increased by 1.22 times. The share of subclinical mastitis accounted for $23.5 \%$ in $2017,22.5 \%$ in 2018 , and $24.5 \%$ in 2019 . Along with this, the seasonality of mastitis was also studied (Figure 1). 


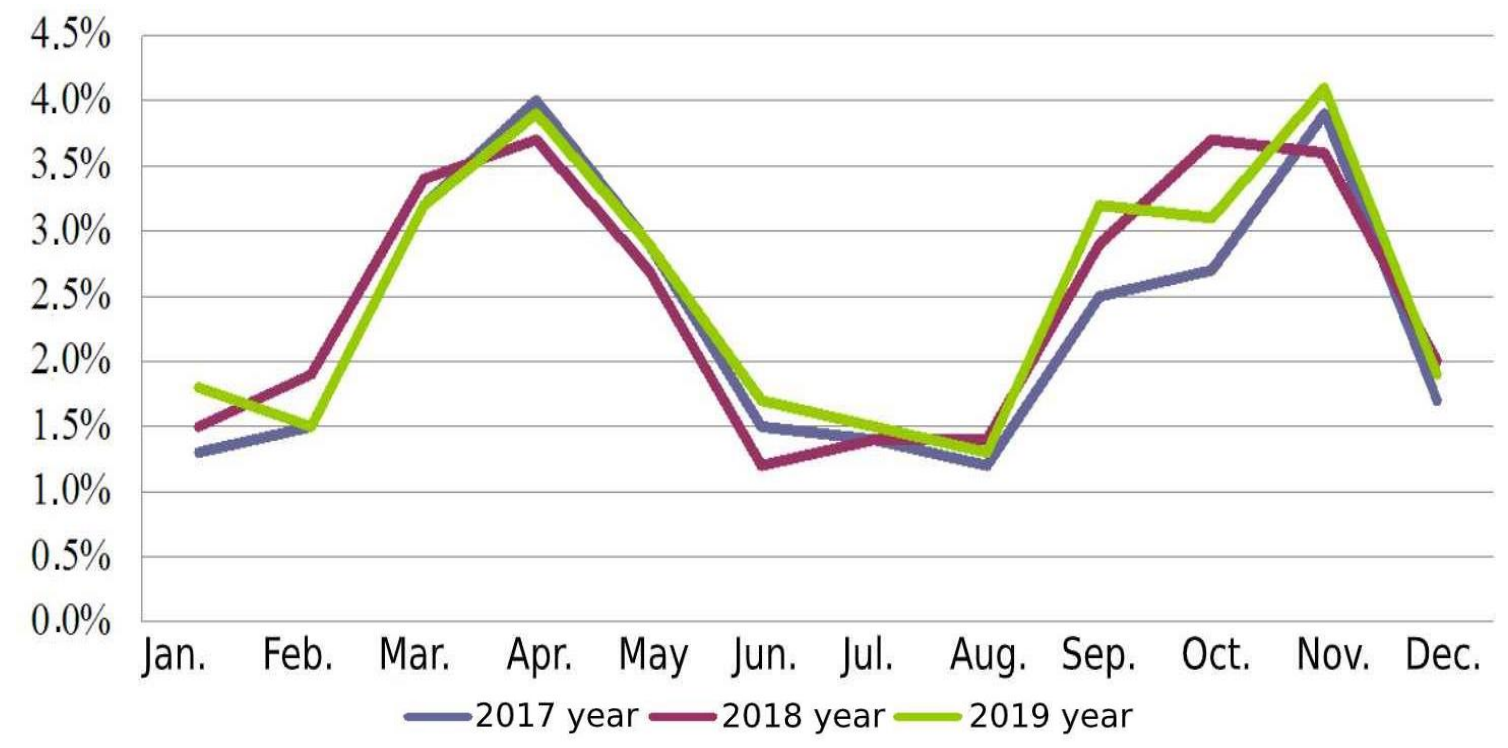

Figure 1. Seasonality of mastitis in cows.

The analysis of the material obtained showed that udder disease in cows at the beginning of lactation has a certain seasonal nature and its main peaks occur in March-May and September-November. During these months, from 2.5 to $4.1 \%$ of ill cows with mastitis were found from the total livestock of the farm, which in our opinion is due to unsatisfactory housing conditions. These reasons led to a decrease in both general and local immunity of the animals. Thus, from December to February, this figure decreased to 1.3$2.0 \%$, and from June to August to $1.2-1.7 \%$ of the total livestock of the farm. Analyzing the data obtained in the study of milk (Table 1), it was found that, with mastitis, there is a change in physicochemical parameters.

Table 1. Physicochemical parameters of cow's milk.

\section{Parameters}

Parameters
Fat, \%
Dry and dry skim milk residue, \%
Density, $\mathrm{kg} / \mathrm{m}^{3}$
Lactose, \%
Salts, \%
Protein, \%
pH
Conductivity, $\mathrm{mS} / \mathrm{cm}$
Somatic cells, thous. $/ \mathrm{cm}^{3}$

\section{Test (clinical mastitis)}

$2.01 \pm 0.17 *$
$7.7 \pm 0.43$
$1026.74 \pm 1.84$
$4.07 \pm 0.23$
$0.66 \pm 0.04$
$2.8 \pm 0.15$
$7.3 \pm 0.09 *$
$7.54 \pm 0.27 * *$
$>1500 \pm 0.0 * *$

\section{Group of animals, $n=15$ II Test (subclinical \\ Control (clinically normal)} mastitis)

$2.51 \pm 0.13$

$8,59 \pm 0,09$

$1029.91 \pm 0.48$

$4.55 \pm 0.05$

$0.72 \pm 0.01$

$3.19 \pm 0.04$

$6.96 \pm 0.06$

$5.92 \pm 0.25^{*}$

$674 \pm 136^{*}$
$3.05 \pm 0.44$

$8.52 \pm 0.33$

$1030.9 \pm 1.97$

$4.50 \pm 0.18$

$0.73 \pm 0.03$

$3.26 \pm 0.18$

$6.72 \pm 0.1$

$4.88 \pm 0.09$

$108 \pm 8.96$

$* \mathrm{P}<0.05 ; * * \mathrm{P}<0.001$ - the difference is statistically-valid

Thus, the decrease in protein by 2.2 and $16.4 \%$ in cows with subclinical and clinical form of mastitis is observed with respect to healthy animals. The content of lactose and dry skim milk residue in cows with clinical mastitis, it decreased by 10.6 and $10.65 \%$ with respect to the control group of cows. The acidity of milk in I and II test groups increased by $8.6 \%$ and $3.6 \%$ in terms compared to the control group. This is explained to the breakdown of milk proteins into ammonia, as well as the influx of sodium bicarbonate from the blood.

We established that with the appearance of subclinical mastitis the access of sodium and chlorine ions from the blood into milk increases, in connection with which, its conductivity increases. In our studies, the conductivity was significantly higher in cows with clinical and subclinical mastitis by 54.5 and $21.3 \%$, respectively. During the study of milk of the animals of I and II test groups, the average number of somatic cells was $>1,500,000$ and $674,000 \mathrm{~mL}^{-1}$, respectively, which can be interpreted as a positive and questionable reaction. The cows of the control group had the number of somatic cells within the physiological norm amounted to $108,000 \mathrm{~mL}^{-1}$.

The microbial factor occupies an important place in the mechanism of development of an inflammation of a mammary gland as in most cases, during bacteriological research, the pathogenic microflora is allocated from a secret of the lobes affected by mastitis. The detection of the species composition of the microflora in the secretion of the mammary glands allows to determine which opportunistic pathogens in this case contribute to the development of mastitis in cows and, further, their titration to antimicrobial drugs. In the microbiological study of milk from 75 cows with mastitis, 16 species of microorganisms were allocated.

In $92.6 \%$ of cows with mastitis, we registered the opportunistic pathogens. When sowing milk from the affected udder lobes on the beef-extract agar in Petri dishes, a massive proliferation of microbial colonies was shown. And, in some cases, at $7.4 \%$ of animals, as a rule, cows with subclinical and serous mastitis, microflora was not allocated in the secret from affected udder lobes, the inflammation proceeded as aseptic (Figure 2). 


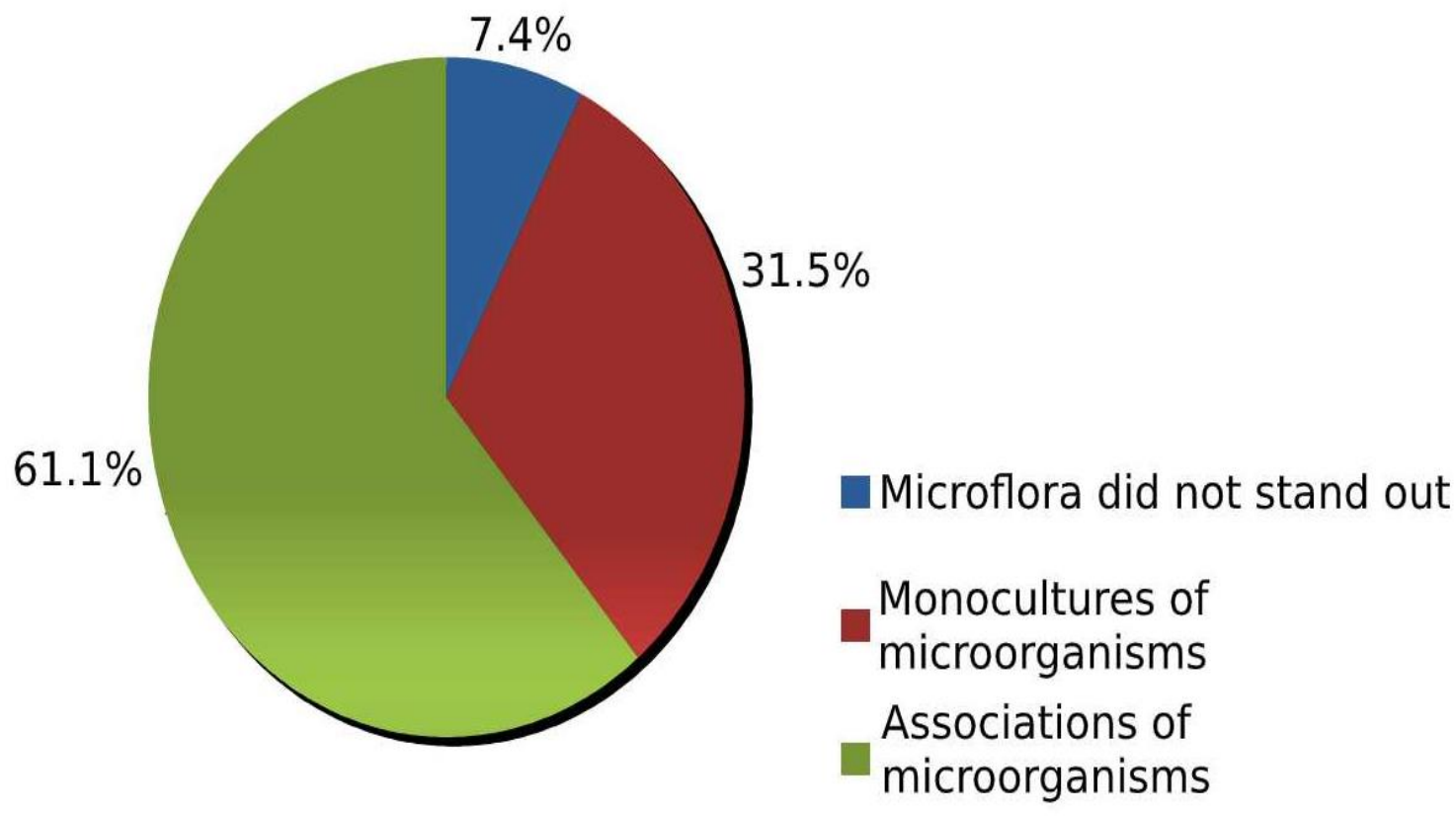

Figure 2. Udder microflora isolated from cows with mastitis.

In monoculture, microflora was isolated from $30.5 \%$ of cows and these were E. coli, St. epidermidis, C. freundi, Sh. dysenteriae, St. aureus, St. hyicus spp. chromogenes, Str. agalactiae, St. lentus, and St. intermedius (Figure 3).

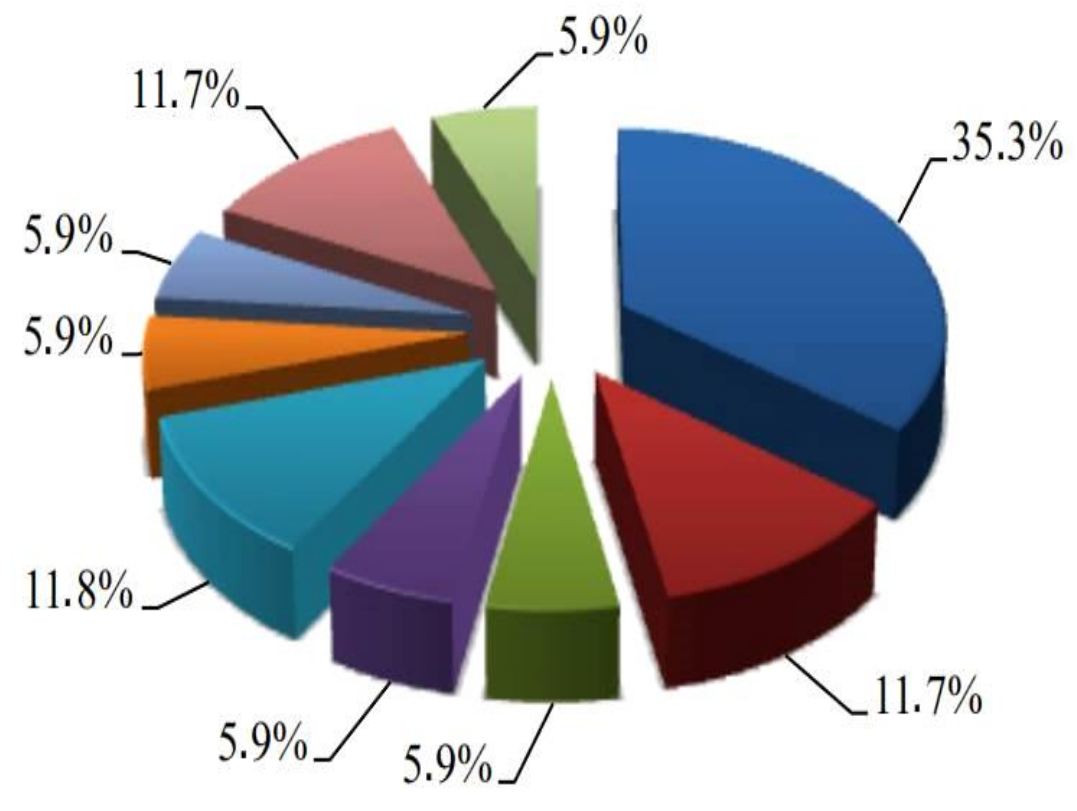

E. coli

\St. epidermidis

C. freundi

Sh. dysenteriae

$\square$ St. aureus

St. hyicus spp. chromogenes

⿶Str. agalactiae

$\square$ St. lentus

$\square$ St. intermedius

Figure 3. Monocultures of microorganisms isolated from the udder of cows with mastitis.

In $69.5 \%$ of cows with mastitis, we registered the microflora in associations. The most common associations were Candida citerrii + Candida glabrata + St. saccharolyticus + St. lentus + C. freundi; Asp. fumigatus + St. epidermidis; Candida rugosa + St. epidermidis + E. coli; E. coli + Str. agalactiae; Str. agalactiae + St. epidermidis; St. epidermidis + St. aureus + Str. agalactiae + Str. haemolyticus; Kl. pneumoniae + Sh. boudi; Y. enterocolliticae + Sh. dysenteriae; Sh. dysenteriae + Sh. boudi; St. epidermidis + St. aureus + Str. agalactiae; St. hominis + St. warrerii + St. epidermidis + Str. agalactiae; St. lentus + St. saccharolyticus + C. freundi; St. epidermidis + E. coli; Str. agalactiae + Str. haemolyticus; St. simulans + Kl. cryocrescens; St. hyicus spp. chromogenes + Kl. cryocrescens; Kl. cryocrescens + St. lentus (Figure 4). 


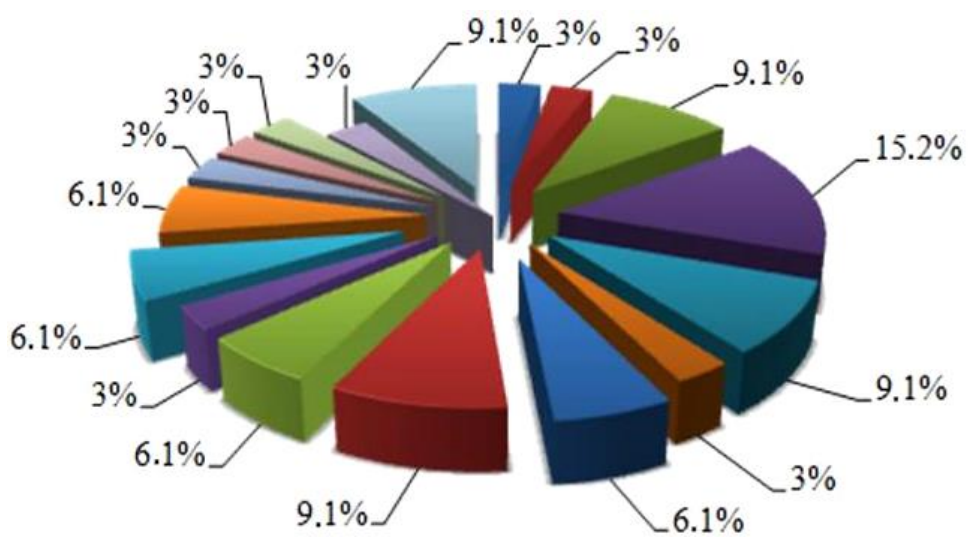

Candida citerrii + Candida glabrata + St. saccharolyticus + St. lentus + C. freundi

Asp. fumigatus + St. epidermidis; Candida rugosa + St. epidermidis + E. coli

$\square$ E. coli + Str. agalactiae

St. epidermidis + St. aureus + Str. agalactiae + Str. haemolyticus

$\square \mathrm{K}$. pneumoniae $+\mathrm{Sh}$. boudi

$\checkmark$ Y. enterocolliticae + Sh. dysenteriae

$\square$ Sh. dysenteriae + Sh. boudi

$\square$ St. epidermidis + St. aureus + Str. agalactiae

$\checkmark$ St. hominis + St. warrerii + St. epidermidis + Str. agalactiae

Q St. lentus + St. saccharolyticus + C. Freundi

$\square$ St. epidermidis + E. coli

$\checkmark$ Str. agalactiae + Str. Haemolyticus

$\square$ St. simulans $+\mathrm{Kl}$. cryocrescens

$\square$ St. hyicus spp. chromogenes $+\mathrm{Kl}$. cryocrescens

$\square \mathrm{K} 1$. cryocrescens + St. lentus

$\square$ Candida rugosa + St. epidermidis + E. coli

Figure 4. Associations of microorganisms isolated from the udder of cows with mastitis.

We concluded that, despite the significant arsenal of antimicrobial drugs, the number of the most active against pathogenic microflora remains fewer and fewer. Therefore, it is necessary to work on finding completely new compositions of antimicrobial drugs. In order to detect the latent form of mastitis in the early stages, we developed the appropriate method, which is performed as follows: at the initial stage, fresh drops of milk in the amount of 2.0-2.5 $\mu$ l obtained from each lobe of the udder are applied to defatted slide $(75 \times 25 \times 1)$, which is located on a horizontal plane. At the next stage, the slide with drops of milk is dried at a temperature of $20 \pm 3^{\circ} \mathrm{C}$ to obtain the structure of the solid phase. Subsequently, the slide is examined under a light microscope and when radial cracks are detected along the edge and in the middle of the drop, subclinical mastitis is diagnosed.

Simultaneously, when examining cows for mastitis, the proposed method was tested. During the approbation, a drop of milk from healthy cows and cows with mastitis was examined under a light microscope. It turned out that when milk from a healthy cow was examined, the edge of the dried drop of milk under the microscope does not contain radial or mosaic areas of cracking. A drop of milk dries evenly without forming cracks (Figure 5).
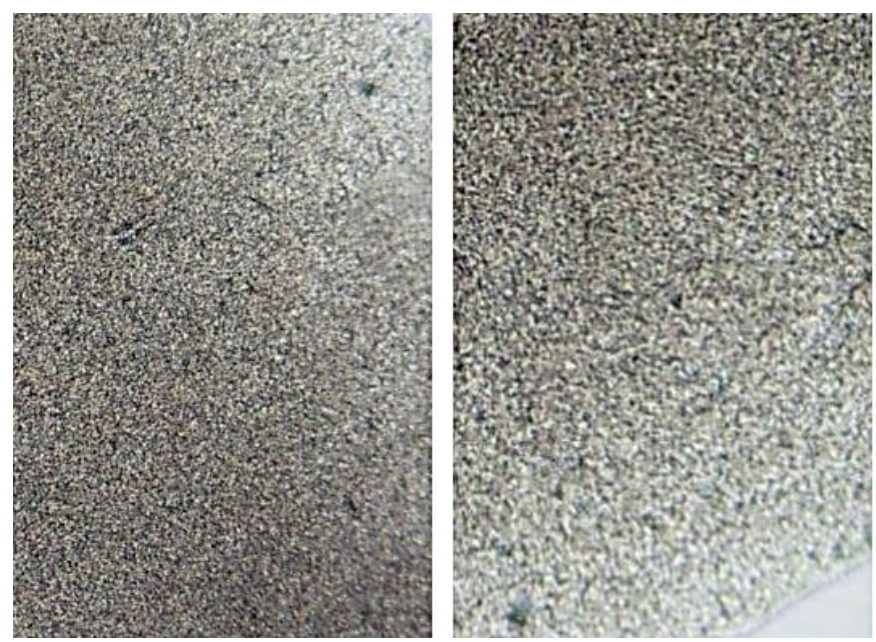

Figure 5. The structure of a milk drop from a healthy cow, $\times 200$.

Distinct mosaic and radial cracks of a surface are visible on the edge and in the middle of the dried drop of milk from cows with subclinical mastitis (Figure 6). 

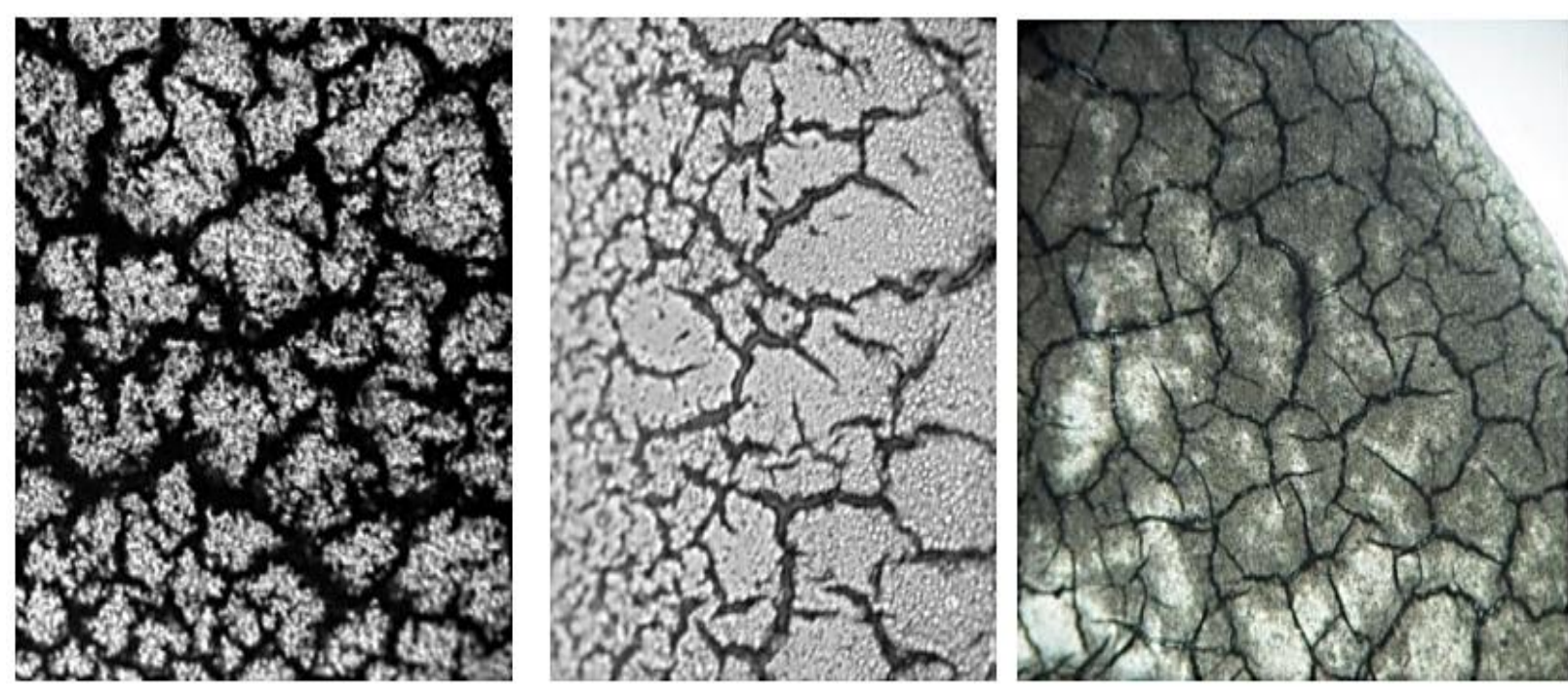

Figure 6. The structure of a milk drop from a cow with subclinical mastitis $(\times 200)$.

We observed that a drop of milk from healthy cows dries evenly without cracking, and that from cows with mastitis forms numerous radial and mosaic cracks in the middle and mainly along the edge, indicating changes in the structure of biological fluid. The examination of a drop of milk under a microscope can be performed on a livestock farm. The data obtained during the study showed that the developed method can be successfully used to detect latent mastitis instead of the method of settling milk samples. The new method allows, along with a rapid mastitis test to detect cows with a latent form of mastitis in the early stages of the disease, which will allow timely treatment of this pathology, as well as evaluate the effectiveness of treatment. This method is one of the most informative, does not require significant economic costs for diagnosis, is easy to set research techniques and analyze the results.

The most important indirect indicator of a healthy udder is the level of somatic cells in milk (Deshapriya et al., 2019; Gokceoglu et al., 2020). Somatic cells are always present in milk, but their level depends on many factors. Due to the constant renewal of epithelial tissue cells, old cells die and end up in milk. Their content is $60-70 \%$ of the total amount. Blood cells leukocytes, which perform protective functions in the body, are added to them. Somatic cells are not able to multiply in expressed milk, unlike bacterial cells. The level of somatic cells in healthy cows ranges from 10,000 to 100,000 per $1 \mathrm{~cm}^{3}$ and usually depends on the individual characteristics of the cow.

\section{Elevated levels of somatic cell levels may indicate parasecretion or disease.}

The importance of mastitis pathology is crucial for both economic and social consequences (Palii \& Palii, 2019). Subclinical mastitis is more common in countries with developed dairy farming, especially in the places where there is a high level of mechanization and automation of production and the most intensive exploitation of animals (Reyes et al., 2019).

The study (Bortolami et al., 2015) has shown during the traditional milk production the number of animals with atrophy (due to mastitis) of one, two or more lobes was $8.4 \%$, and in herds of dairy complexes $-10.33 \%$. The scientists have been interested in the causes of subclinical mastitis for a long time, but so far veterinarians did not come to a consensus on the paramount importance of certain factors in the development of this pathology. A number of factors are considered to be the causes of subclinical mastitis: it is an infectious origin and environmental factors, such as violations of veterinary and zootechnical regulations, postpartum complications and injuries of the musculoskeletal system (Klaas \& Zadoks, 2017; Palii et al., 2020c).

Despite the recognition by most authors (Adkins \& Middleton, 2018; Samson et al., 2016) of the role of microbial factor in the development of mastitis, subclinical mastitis in the nosological profile is not presented as an infectious disease. This is facilitated by such factors as its polyetiology, relatively low possibility of infection, as well as the traditional notion that the disease is associated with environmental conditions (feeding and milking). A number of authors (Nolan, 2017; Paliy, 2019) indicate that mastitis causes a decrease in quality of milk (density, acidity, fat content, dry and dry skim milk residue and increased bacterial contamination) and products derived from it.

Mastitis is one of the most common diseases of dairy cattle in the world (Doehring \& Sundrum, 2019; Kock et al., 2018; Palii et al., 2020d), despite the widespread introduction of mastitis prevention technologies. Various microorganisms can be a causative agent of the disease: bacteria, mycoplasmas, yeast and algae. Mastitis can be classified into two types: infectious pathogenesis and environmental pathogenesis. Pathogens of infectious pathogenesis exist inside the infected part of the udder. They lead to subclinical mastitis, which usually manifests itself in the form of an increase in the number of somatic cells (leukocytes and epithelial cells) in the milk from the affected lobe (Zhelavskyi \& Dmytriv, 2018). Pathogens are transmitted from cow to cow or from one part of the udder to another, as well as during milking through towels for wiping the hands of milking operators and milking machines. The most common pathogens of this type are Staphylococcus aureus, Streptococcus agalactiae, Streptococcusdis dysgalactiae and Corynebacterium bovis. Streptococcus agalactiae, Staphylococcus aureus and Mycoplasma (bovis) are the main organisms that cause infectious mastitis.

Streptococcus agalactiae (Str. Agalactiae) are the gram-positive bacteria that inhabit the capacitive system of the udder (small, medium and large ducts and the cistern of the mammary gland). They cause inflammation that blocks the ducts and leads to a decrease in milk production, an increase in the number of somatic cells, and ultimately to the involution of the alveolar apparatus. In addition, there are several enzymes/toxins in the capacitive system of the udder that are very sensitive to antibiotics (Werner et al., 2018). Staphylococcus aureus (St. aureus) is the main cause of mastitis. It causes acute, chronic and subclinical mastitis. These bacteria produce many enzymes/toxins (catalase and coagulase), they are highly aggressive (produce hyaluronidase, which allows them to invade tissues) and have the ability to resist phagocytosis (produce thiachuronic acid). St. aureus are optional intracellular parasites (can live inside phagocytes), moderately stable in the environment. They are often found in the mammary glands of for 
the first time calving animals. They are the main cause of mastitis in heifers. Some strains of St. aureus are resistant to antibiotics due to genetic mutations (Lundberg et al., 2016).

Mycoplasmas, polymorphic organisms (they do not have a cell wall) are often excreted from the respiratory and urogenital tracts. They cause enzootic mastitis, against which there is no effective treatment. Infected cows should be isolated or culled (Krömker \& Leimbach, 2017; Palii et al., 2020e).

The most common microorganisms associated with the environment are Esherichia coli and Streptococcus uberus. The vast majority of mastitis of bacterial origin ( $80 \%$ of cases) is caused by five species of bacteria, namely Escherichia coli, Streptococcus uberis, Staphylococcus aureus, Streptococcus dysgalactiae and Streptococcus agalactiae (Hadzevych et al., 2019).

The relationship between vacuum change and the incidence of new cases of mastitis has been established (Paliy et al., 2018). At the same time, the microorganisms easily get into the teat duct. Most often this occurs as a result of equipment failure: changes in air flow rate in vacuum, the degree of vacuum and twisting of hoses. In addition to the level of vacuum in the milking system and mode, according to Paliy et al. (2020), the quality of teat rubber is of particular importance. Significant influence on the development of mastitis in animals is exerted by non-compliance with the requirements of pre-milking preparation for machine milking, which reduces milk productivity by $27 \%$ and milking intensity by $16-40 \%$ (Degen et al., 2015; Palii, 2019). Palii et al. (2019) noted that increasing the duration of an 'idle' milking increases the risk of mastitis by up to $20 \%$, as it causes the damage of the udder tissue.

Incomplete milking leads to premature self-initiation of the animal and reduces the resistance of the udder to mastitis. Currently, farmers pay great attention to the quality and quantity of milk produced, which largely depends on the genetic potential of cows, technology of keeping, feeding and milking animals. Economic profit directly depends on the level of production and therefore the selection of lactating cows in some countries is carried out strictly according to the quality and quantity of milk produced.

Therefore, the mastitis treatment requires the long-term and persistent efforts. Whereas it is impossible to completely prevent the transmission of bacteria and other microorganisms caused the disease, it is expedient to provide a comprehensive approach that includes diagnosis and prevention of the disease.

\section{Conclusion}

We found that the indicative properties of milk from cows with subclinical and clinical mastitis are an increase in number of somatic cells to $674,000 / \mathrm{cm}^{3}$ and $>1,500,000 / \mathrm{cm}^{3}$, respectively, raising the $\mathrm{pH}$ of milk to $6.96-7.3$, which is associated with the breakdown of milk proteins into ammonia, the increase in the electrical conductivity of milk to $5.92-7.54 \mathrm{mS} / \mathrm{cm}$ associated with the entry of sodium and chlorine ions from the blood into the milk.

In cows with mastitis, 16 species of bacteria were isolated from the secretion of the udder. In monoculture, the microflora, that was found in $30.5 \%$ of cows, consisted of E. coli, St. epidermidis, C. freundi, Sh. dysentery, St. aureus, St. hyicus spp. chromogenes, Str. Agalactiae, St. lentus, and St. intermediate. In $69.5 \%$ of cows with mastitis, the microflora was presented by associations. The most common associations of bacteria were St. epidermidis + St. aureus + Str. agalactiae + Str. Haemolyticus, E. coli + Str. Agalactiae, Str. agalactiae + St. epidermidis, St. epidermidis + St. aureus + Str. agalactiae.

The proposed method for diagnosing dairy cattle mastitis, based on dried milk drop microscopy on a glass slide, allows to detect the latent form of mastitis at early stages.

\section{References}

Adkins, P., \& Middleton, J. (2018). Methods for Diagnosing Mastitis. Veterinary Clinics of North America - Food Animal Practice, 34, 479-491.

Ashraf, A., \& Imran, M. (2018). Diagnosis of bovine mastitis: from laboratory to farm. Tropical Animal Health and Production, 50, 1193-1202.

Asma, A., Salem, D., Latif, M., \& Moula, N. (2019). Evaluation of the Prevalence of Subclinical Mastitis in Dairy Cattle in the Soummam Valley (Bejaia, Algeria). Bulletin of University of Agricultural Sciences and Veterinary Medicine Cluj-Napoca. Horticulture, 76(2).

Bezman, D., Kuzinl, L. L., Katzl, G., Merin, U., \& Leitner, G. (2015). Influence of intramammary infection of a single gland in dairy cows on the cow's milk quality. Journal of Dairy Research, 82, 304-311.

Bobbo, T., Ruegg, P. L., Stocco, G., Fiore, E., Gianesella, M., Morgante, M., Pasotto, D., Bittante, G., \& Cecchinato, A. (2017). Associations between pathogen-specific cases of subclinical mastitis and milk yield, quality, protein composition, and cheese-making traits in dairy cows. Journal of Dairy Science, 100, 4868-4883.

Bortolami, A., Fiorel, E., Gianesella, M., Corro, M., Catania, S., \& Morgante, M. (2015). Evaluation of the udder health status in subclinical mastitis affected dairy cows through bacteriological culture, somatic cell count and thermographic imaging. Polish Journal of Veterinary Sciences, 18, 799-805.

Buzoverja, M. J., Shherbak, J. P., Shishpor, I. V., \& Potehina, J. P. (2012). Mikrostrukturnyj analiz biologicheskih zhidkostej. Zhurnal tehnicheskoj fiziki, 82(7), 123-128.

Degen, S., Paduch, J.-H., Hoedemaker, M., \& Krömker, V. (2015). Factors affecting the probability of bacteriological cure of bovine mastitis. Tierärztliche Praxis. Grosstiere/Nutztiere, 43(3).

Deshapriya, R. M. C., Rahularaj, R., \& Ranasinghe, R. M. S. B. K. (2019). Mastitis, Somatic cell count and milk quality ; an overview. Sri Lanka Journal of Child Health, 66(1), 1-12.

Doehring, C., \& Sundrum, A. (2019). The informative value of an overview on antibiotic consumption, treatment efficacy and cost of clinical mastitis at farm level. Preventive Veterinary Medicine, 165.

Freitas, L., Cerqueira, P., Marques, H., Leandro, R., \& Machado, P. (2017). Human behavioral influences and milk quality control programs. Animal, 12(3), 1-6.

Gokceoglu, A., Yarim, G., Gultiken, N., \& Yarim, M. (2020). High epidermal growth factor concentration associated with somatic cell count in milk of cows with subclinical mastitis. Medycyna Weterynaryjna, 76. 6396-2020.

Hadzevych, O. V., Paliy, A. P., Kinash, O. V., Petrov, R. V., \& Paliy, A. P. (2019). Antibiotic resistance of microorganisms isolated from milk. World of Medicine and Biology, 3(69), 245-250.

Haenni, M., Lupo, A., \& Madec, J.-Y. (2018). Antimicrobial Resistance in Streptococcus spp. Microbiology Spectrum, 6. 
Heikkilä, A.-M., Liski, E., Pyörälä, S., \& Taponen, S. (2018). Pathogen-specific production losses in bovine mastitis. Journal of Dairy Science, 101, 9493-9504.

Klaas, I., \& Zadoks, R. (2017). An update on environmental mastitis: Challenging perceptions. Transboundary and Emerging Diseases, 65/1(8).

Kock, J., Wente, N., Zhang, Y., Paduch, J.-H., Leimbach, S., Klocke, D., Gelfert, C., \& Krömker, V. (2018). Udder health effects of an evidence-based mastitis therapy concept in Northwestern Germany. Milchwissenschaft, 71(1), 14-19.

Krömker, V., \& Leimbach, S. (2017). Mastitis treatment - Reduction in antibiotic usage in dairy cows. Reproduction in Domestic Animals, 52(3), 21-29.

Leimbach, S., \& Krömker, V. (2018). Laboratory evaluation of a novel rapid tube test system for differentiation of mastitis-causing pathogen groups. Journal of Dairy Science, 101(7).

Lundberg, Å., Nyman, A.-K., Aspán, A., Börjesson, S., Unnerstad, H., \& Waller, K. (2016). Udder infections with Staphylococcus aureus, Streptococcus dysgalactiae, and Streptococcus uberis at calving in dairy herds with suboptimal udder health. Journal of Dairy Science, 99(3), 1-16.

Nolan, D. T. (2017). An Examination of Milk Quality Efects on Milk Yield and Dairy Production Economics in the South eastern United States. Theses and Dissertations-Animal and Food Sciences, 71. University of Kentucky, UKnowledge.

Palii, A. P., Admina, N. G., Mihalchenko, S. A., Lukyanov, I. M., Denicenko, S. A., ... Solodchuk, A. V. (2020a). Evaluation of slaughter cattle grades and standards of cull cows. Ukrainian Journal of Ecology, 10(1), 162-167.

Palii, A. P., Mihalchenko, S. A., Chechui, H. F., Reshetnichenko, A. P., Rozum, Y. E., ... Paliy, A. P. (2020d). Milking and udder health assessment in industrial farming. Ukrainian Journal of Ecology, 10(2), 375-381.

Palii, A. P., Nanka, O. V., Naumenko, O. A., Prudnikov, V. G., \& Paliy, A. P. (2019). Preconditions for eco-friendly milk production on the modern dairy complexes. Ukrainian Journal of Ecology, 9(1), 56-62.

Palii, A. P., \& Palii, A. P. (2019). Technical and technological innovations in dairy cattle. Monograph. Kharkiv. Mis'kdruk (In Ukrainian)

Palii, A. P., Paliy, A. P., Rodionova, K. O., Zolotaryova, S. A., Kushch, L. L., ... Umrihina, O. S. (2020c). Microbial contamination of cow's milk and operator hygiene. Ukrainian Journal of Ecology, 10(2), 392-397.

Palii, A. P., Rodionova, K. O., Paliy, A. P., Kushch, L. L., Matsenko, O. V., ... Honcharenko, H. O. (2020b). Effect of colostral bacterial contemination on the calves. Ukrainian Journal of Ecology, 10(3), 76-82.

Palii, A. P., Shkromada, O. I., Todorov, N. I., Grebenik, N. P., Lazorenko, A. B., ... Paliy, A. P. (2020e). Effect of linear traits in dairy cows on herd disposal. Ukrainian Journal of Ecology, 10(3), 88-94.

Palii, A. P. (2019). Vplyv sanitarno-gigijenichnogo stanu koriv na jakist' moloka z rozrobkoju kompleksnoi' systemy ocinjuvannja gigijeny tvaryn. Tavrijs'kyj naukovyj visnyk, 105, 174-180.

Paliy, A., Nanka, A., Marchenko, M., Bredykhin, V., Paliy, A., ... Musiienko, O. (2020). Establishing changes in the technical parameters of nipple rubber for milking machines and their impact on operational characteristics. Eastern-European Journal of Enterprise Technologies, 2/1(104), 78-87.

Paliy, A. P. (2016). Innovative foundations for the production of high-quality milk. Monograph. Kharkiv. Mis'kdruk (In Ukrainian)

Paliy, A. P., Nanka, O. V., Lutcenko, M. M., Naumenko, O. A., \& Paliy, A. P. (2018). Influence of dust content in milking rooms on operation modes of milking machine pulsators. Ukrainian Journal of Ecology, 8(3), 66-70.

Paliy, A. P. (2019). Research of technological methods for preparing highly productive cows for milking. Scientific and Technical Bulletin, 121, 181-190.

Paliy, A. P. (2018). Vdoskonalennja tehnologichnogo rishennja dlja diagnostychnyh doslidzhen' u molochnomu skotarstvi. Naukovo tehnichnyj bjuleten' Instytutu tvarynnyctva NAAN, 120, 78-85.

Reyes, V. J., Rodriguez-Lecompte, J., Blanchard, A., Mcclure, J. T., \& Sánchez, J. (2019). Molecular variability of Streptococcus uberis isolates from intramammary infections in Canadian dairy farms from the Maritime region, 83. 168-176.

Samson, O., Gaudout, N., Schmitt, E., Schukken, Y., \& Zadoks, R. (2016). Use of on-farm data to guide treatment and control of mastitis caused by Streptococcus uberis. Journal of Dairy Science, 99(9).

Shkromada, O., Skliar, O., Paliy, A., Ulko, L., Gerun, I., ... Paliy, A. (2019). Development of measures to improve milk quality and safety during production. Eastern-European Journal of Enterprise technologies (Technology and equipment of food production), 3/11(99), 30-39.

Silva, S. D., Kanugala, K., \& Weerakkody, N. (2016). Microbiological quality of raw milk and effect on quality by implementing good management practices. International Conference of Sabaragamuwa University of Sri Lanka, 92-96.

Soest, F. J. S., Berends, I. M. G. A., Lam, T. J. G. M., \& Hogeveen, H. (2016). Failure and preventive costs of mastitis on Dutch dairy farms. Journal of Dairy Science, 99(10).

Vliegher, S. D., Fox, L. K., Piepers, S., McDougall, S., \& Barkema, H. W. (2012). Invited review: Mastitis in dairy heifers: Nature of the disease, potential impact, prevention, and control. Journal of Dairy Science, 95, 1025-1040.

Wente, N., Klocke, D., Paduch, J.-H., Zhang, Y., Seeth, M., ... Krömker, V. (2019). Associations between Streptococcus uberis strains from the animal environment and clinical bovine mastitis cases. Journal of Dairy Science, 102(10).

Werner, C., Sauerwald, C., Sundrum, A., El-Sayed, A., \& Zschöck, M. (2018). Genotyping of Streptococcus uberis isolates in healing process of bovine clinical mastitis. International Journal of Veterinary Science and Medicine, 6.

Wolfenson, D., Leitner, G., \& Lavon, Y. (2015). The Disruptive Effects of Mastitis on Reproduction and Fertility in Dairy Cows. Italian Journal of Animal Science, 14(4).

Zhelavskyi, M., \& Dmytriv, O. Ya. (2018). Immunobiological status of the body of cows during mastitis. Scientific Messenger of LNU of Veterinary Medicine and Biotechnologies, 20, 3-10.

\section{Citation:}

Palii, A.P., Ulko, Y.S., Bogomolov, O.O., Kis-Korkishchenko, L.V., Kambur, M.D., Zamaziy, A.A., Brit, N.M., Boiko, I.M., Grebnova, I.V., Kovalchuk, Y.O., Paliy, A.P. (2020). Species composition of microbiota of cows udder and raw milk quality at mastitis. Ukrainian Journal of Ecology, $10(3), 78-85$. 